\title{
Perancangan Sistem Pendukung Keputusan Dalam Memilih Sekolah Tinggi Ilmu Kesehatan di Yogyakarta
}

\author{
Norhikmah*1, Kusrini², M.Rudyanto Arief ${ }^{3}$ \\ 1,2,3 Magister Teknik Informatika STMIK AMIKOM Yogyakarta \\ E-mail: *1 hikmah@amikom.ac.id, ${ }^{2}$ kusrini@ amikom.ac.id, ${ }^{2}$ rudy@ amikom.ac.id
}

\begin{abstract}
Abstrak
Seorang calon mahasiswa yang ingin melanjutkan jenjang pendidikannya ke sekolah tinggi ilmu kesehatan bukan suatu persoalan yang mudah, banyak pertimbangan yang harus dipertimbangkan seperti biaya selama perkuliahan, lowongan perkerjaan, kerjasama kampus tersebut dengan instansi terkait, dan lain-lain. Sampel kriteria yang digunakan dalam perancangan prototipe sistem pendukung keputusan dalam memilih Sekolah Tinggi Ilmu Kesehatan (STIKES) adalah kriteria yang didapatkan dari jawaban kuesioner sesuai dengan hasil uji validitas disetiap variable kriterianya. Proses pengambilan keputusan dalam memilih sekolah tinggi ilmu kesehatan ini menggunakan penggabungan 2 metode yaitu AHP dan F-AHP yang memiliki tujuan agar dapat mengurangi penilaian secara subyektivitas dan mengecek konsistensi logic antar kriteria maupun subkriteria, sehingga dapat menghasilkan ranking sekolah tinggi ilmu kesehatan yang lebih objektif, serta dapat membantu memberikan rekomendasi STIKES mana yang layak untuk dipilih,.
\end{abstract}

Kata Kunci - Sistem Pendukung Keputusan, Fuzzy, AHP, Sekolah Tinggi Ilmu Kesehatan

\begin{abstract}
A prospective student who wants to continue his education to high school health science is not an easy matter, many considerations that must be taken into account as expenses for tuition, job vacancies, the campus co-operation with relevant agencies, and others. Sample criteria used in the design of a prototype decision support system in choosing the College of Health Sciences ( STIKES ) is the criterion obtained from the results of the questionnaire were tested for validity every variable criteria. The decision making process in choosing a high school health science using two methods, namely the incorporation of $F-A H P$ and AHP which has the aim to reduce the subjectivity of assessment and check the consistency between the criteria and sub-criteria, so as to produce a high-ranking school objectives of health sciences, as well as STIKES can help provide recommendations which are feasible for selected
\end{abstract}

Keywords - Decision Support Systems , Fuzzy, AHP, College of Health Sciences 


\section{PENDAHULUAN}

Pada era sekarang kebutuhan untuk meneruskan pendidikan kejenjang yang lebih tinggi sudah meningkat. Paper yang berjudul "Sistem pendukung keputusan untuk menentukan pilihan minat perguruan tinggi di kota jambi dengan menggunakan Fuzzy Multi Criteria Decision Making (FMCDM)". Menyatakan bahwa "Banyak faktor yang mempengaruhi orang untuk belajar di perguruan tinggi dari niat diri sendiri untuk belajar, sekedar untuk mengambil gelar dan juga hanya ikut-ikutan"[1]. Dari beberapa faktor yang disebutkan diatas, terkadang membuat calon mahasiswa kurang tepat dalam memilih perguruan tinggi yang sesuai dengan minat dan keahliannya, terutama dalam memilih sekolah tinggi ilmu kesehatan yang dimana bidang ilmu kesehatan tidak hanya minat dari calon mahasiswanya tetapi biaya yang akan dikeluarkan selama perkuliahan, status akreditasi, dan fasilitas laboratorium yang dimiliki kampus yang kita pilih, lokasi kampus dan prasarana dan sarana kampus.

Tujuan penelitian ini adalah: 1) Untuk mengetahui kriteria apa saja yang dipilih/dipertimbangkan dalam memilih sekolah tinggi ilmu kesehatan di Yogyakarta sesuai dengan hasil uji validitas. 2) Untuk menerapkan metode AHP dan Fuzzy AHP dalam memilih sekolah tinggi ilmu kesehatan di Yogyakarta.3) Merancang Prototipe sistem pendukung keputusan dalam memilih sekolah tinggi ilmu kesehatan di Yogyakarta.4) Dengan Menggunakan aplikasi prototipe sistem pendukung keputusan dapat mengetahui hasil pemilihan sekolah tinggi ilmu kesehatan yang terbaik sesuai dengan penilaian nilai kriteria yang dipilih.

Batasan penelitian ini adalah:1) Penelitian ini hanya menggunakan kriteria yang didapatkan dari hasil uji validitas.2) Penelitian dalam memilih sekolah tinggi ilmu kesehatan ini hanya menggunakan Model AHP dan Fuzzy AHP.3) Penelitian ini hanya dilakukan sampai tahap uji coba program prototipe.4) Sofware yang digunakan dalam penilitian ini adalah:a) Ms.Exel 2010.b) Aptana dan Xampp.c) Browser Firefox.5) Penelitian perancangan hanya berupa prototipe dalam memilih sekolah tinggi ilmu kesehatan di Yogyakarta, yang memiliki batasan sebagai berikut:a) Login level admin atau member.b) Menampilkan data kriteria dan memilih kriteria.c) Menampilkan dan memilih data kampus.d) Memasukkan nilai Kampus.e) Memasukkan data perbandingan matrix.f) Menghitung secara otomatis konsistensi dan proses perangkingan.g) Melihat hasil ranking STIKES.

Penelitian sebelumnya "Sistem Pendukung keputusan dengan Proses Analitik Hirarki (AHP) digunakan untuk memecahkan suatu persoalan dalam suatu kerangka berpikir yang terorganisir, sehingga memungkinkan dapat diekspresikan untuk mengambil keputusan yang efektif atas persoalan tersebut.Sistem pendukung keputusan ini dibuat sebagai bahan pembantu pendukung keputusan user/calon mahasiswa untuk menentukan perguruan tinggi yang akan dimasuki"[2].dan penelitian "Pemilihan Karyawan terbaik merupakan persoalan pengambilan keputusan menggunakan multi kriteria (Multi Criteria Decision Making /MCDM), pada makalah ini, dibangun sistem pendukung keputusan pemilihan karyawan terbaik pada PT " $X$ " menggunakan kriteria antara lain : SOP (standart Operational Procedure). Sikap dan kepribadian, penilaian Konsumen, dan penilaian dari lingkungan kerja tim, metode yang digunakan adalah Fuzzy AHP'[3].

Sedangkan Penelitian yang dilakukan penulis adalah merancang sistem pendukung keputusan untuk membantu calon mahasiswa dalam memilih perguruaan tinggi ilmu kesehatan di Yogyakarta dengan menerapkan AHP dan Fuzzy AHP, dengan penggabungan 2 metode tersebut dalam mengurangi penilaian secara subyektivitas,mengetahui konsistensi logic antar kriteria maupun kriteria,sehingga dapat menghasilkan ranking sekolah tinggi ilmu kesehatan yang lebih objektif.

Dss merupakan sistem informasi interaktif yang menyediakan informasi, permodelan, dan pemanipulasian data.Sistem ini digunakan untuk membantu pengambilan keputusan dalam situasi yang semiterstruktur dan tidak terstruktur[4]

Arsitektur Aplikasi DSS dapat terdiri dari subsistem manajemen data, subsistem manajemen model, subsistem antarmuka pengguna, dan subsistem manajemen berbasis pengetahuan[5]. 
Proses pengambilan keputusan mempunyai empat tahapan, yaitu, kecerdasan, desain, pilihan, dan implementasi. Tahap intelijen menyelidiki keterlibatan lingkungan, baik bersifat sementara atau terus menerus [5].

\section{METODE PENELITIAN}

. Metode penelitian yang dilakukan untuk menganalisa permasalahan diatas dilakukan dalam beberapa tahapan, sebagai berikut:

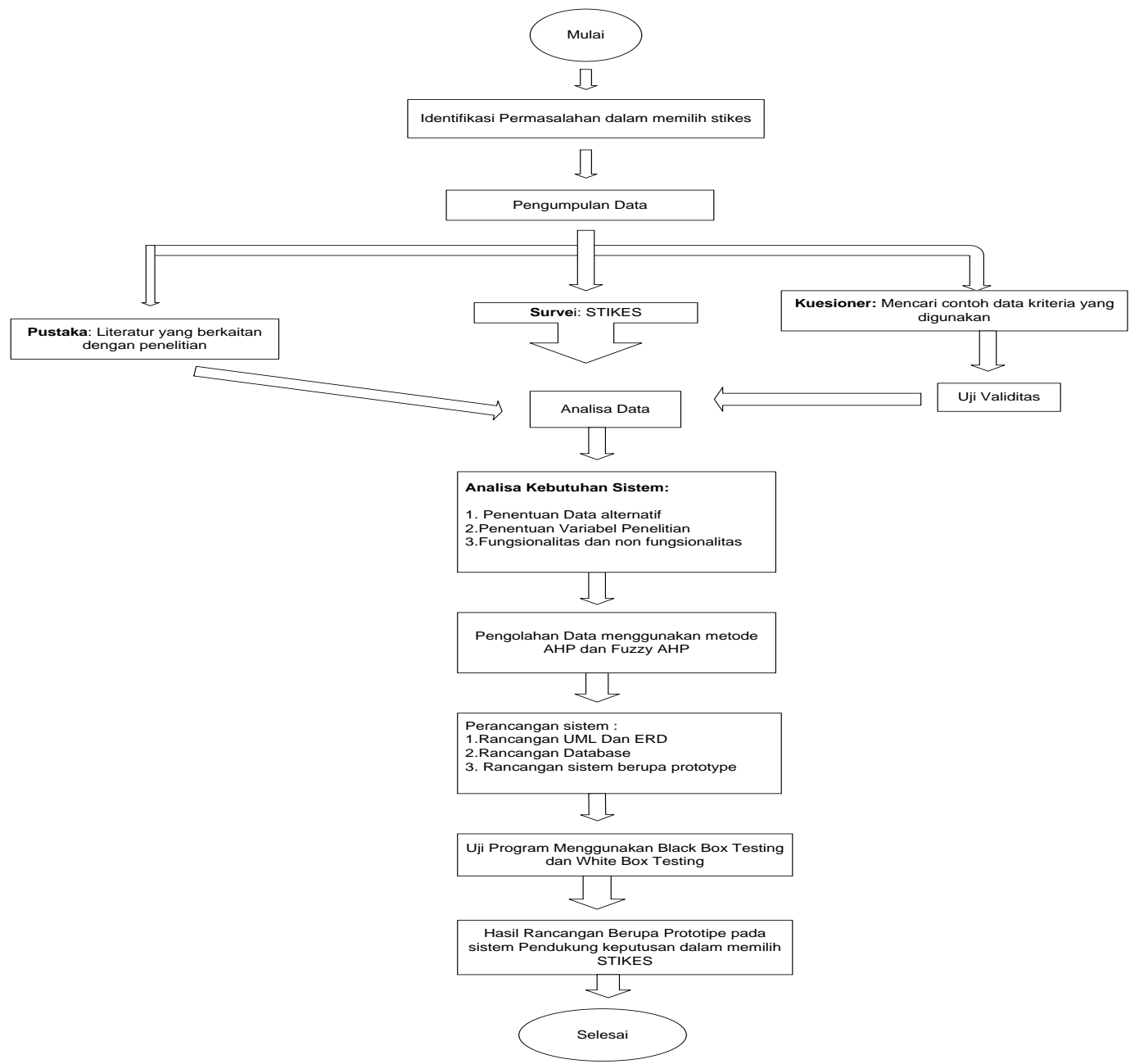

Gambar 1. Diagram Alir Penelitian

\subsection{Metode Pengumpulan Data}

Pada Gambar 1. diatas terdapat beberapa tahapan dalam penelitian yang dilakukan, Berikut Penjelasannya:

1. Identifikasi Permasalahan yang menyebabkan kesulitan dalam memilih STIKES.

2. Pengumpulan Data, yang terbagi menjadi tiga tahapan bagian penelitian:

a. Pustaka : Mencari literatur yang berkaitan dengan penelitian.

b. Survei : Mencari data- data yang berkaitan dengan STIKES.

c. Kuesioner : Mencari contoh data kriteria yang digunakan dalam memilih STIKES.

3. Uji Validitas dilakukan untuk mengetahui kevalidan dalam memilih kriteria.

4. Analisa Data : Menganalisa data yang dibutuhkan dalam pemilihan STIKES. 
5. Analisa Kebutuhan Sistem yaitu penentuan data alternatif, data variabel penelitian, dan fungsionalitas serta non fungsionalitas.

6. Pengolahan data menggunakan metode AHP dan Fuzzy AHP : Metode yang digunakan dalam proses perhitungan untuk pemilihan STIKES.

7. Perancangan Sistem berupa rancangan UML,ERD dan Database, rancangan sistem berupa prototipe.

8. Uji Program menggunakan black box testing dan white box testing

9. Hasil rancangan berupa prototipe pada sistem pendukung keputusan STIKES : Aplikasi pemilihan STIKES berupa prototipe.

\subsection{Metode Analisa Data}

Metode analisa data hasil penelitian ini yang berupa jawaban dari kuesioner dengan menggunakan uji validitas.

\section{HASIL DAN PEMBAHASAN}

Dari hasil observasi penelitian ini didapatkan jumlah data sekolah tinggi ilmu kesehatan dikota Yogyakarta memiliki 9 STIKES yang masih aktif dan tercatat resmi dikovertis 5 serta dikti yang tersebar dibeberapa kabupaten yaitu:Kodya Yogyakarta, Sleman, dan Bantul.Berikut listnya.

Tabel 1. List Data Kampus/Alternatif

\begin{tabular}{|l|l|}
\hline \multicolumn{1}{|c|}{ Nama } & \multicolumn{1}{c|}{ Daerah } \\
\hline Kampus A & Bantul \\
\hline Kampus B & Kodya Jogja \\
\hline Kampus C & Kab Sleman \\
\hline
\end{tabular}

Tabel 1. adalah contoh list data kampus yang diambil sebagai perwakilan perkabupaten yang dijadikan sampel data alternatif atau data kampus dalam penelitian ini.

\subsection{Penentuan Kriteria}

Dalam penelitian ini peneliti mengambil sampel kriteria dengan menyebar kuesioner ke mahasiswa STIKES Yogyakarta. Dengan jumlah populasi mahasiswa STIKES Yogyakarta adalah 54.622 orang mahasiswa. Rumus untuk menentukkan jumlah sampel [6], sebagai berikut:

Dalam penelitian ini peneliti mengambil sampel kriteria dengan menyebar kuesioner ke mahasiswa STIKES Yogyakarta. Dengan jumlah populasi mahasiswa STIKES Yogyakarta adalah 54.622 orang mahasiswa. Rumus untuk menentukkan jumlah sampel [6], sebagai berikut:

$$
\mathrm{n}=\mathrm{N} /\left(1+\mathrm{Ne}^{2}\right)
$$

Keterangan:

$\mathrm{n}=$ Ukuran (jumlah) sampel.

$\mathrm{N}=$ Ukuran (jumlah) populasi.

$\mathrm{e}=$ Nilai Kritis (Batas ketelitian.batas signifikansi) yang diinginkan akibat kesalahan dalam pengambilan sampel.

Diketahui Jumlah Populasi 54.622 mahasiswa, batas kesalahan (taraf signifikasi) yang digunakan dalam penelitian ini adalah $10 \%$. Berikut cara perhitungan:

$$
\mathrm{n}=54622 /(1+(54622(0.01 * 0.01)))=54622 / 54762=99.817=100 \text { Mahasiswa }
$$


Jadi dapat disimpulkan minimal sampel yang diambil dalam penelitian ini adalah 100 mahasiswa. STIKES yang diambil sampel untuk responden berdasarkan perwakilan perkabupaten. Dalam penelitian ini jumlah mahasiswa yang menjadi sampel adalah 106 orang mahasiswa yang tersebar yaitu 40 dari kabupaten Bantul, 48 dari Kabupaten Sleman, 18 dari Kodya Yogyakarta.

\subsection{Uji Validitas}

Kuesioner merupakan salah satu instrument penelitian untuk menggali informasi secara langsung. Informasi yang didapat dari kuesioner perlu diuji validitas. Uji validitas menunjukkan apakah kuesioner tersebut mampu mengukur apa yang harus diukur[7]. Dengan rumus uji validitas atau $\mathrm{r}_{\text {hitung }}$ sebagai berikut:

$$
r x y=\frac{n \sum X Y-\left(\sum X\right)\left(\sum Y\right)}{\sqrt{\left\{n \sum X^{2}-\left(\sum X\right)^{2}\right\}\left\{n \sum Y^{2}-\left(\sum Y\right)^{2}\right\}}}
$$

Keterangan:

$\mathrm{x}=$ Hasil kuesioner Pertayaan ke- $\mathrm{i}$

$\mathrm{y}=$ Jumlah Keseluruhan dari hasil Kuesioner

Uji validitas dilakukan pada tiap butir pertayaan. Hasilnya jika dibandingkan dengan $r$ tabel dengan $\mathrm{df}=\mathrm{N}-\mathrm{K}$ dan dengan nilai alfa $=0,05$

1. Jika $\mathrm{r}_{\text {hitung }}<\mathrm{r}_{\text {tabel }}=$ tidak valid

2. Jika $r_{\text {hitung }}>r_{\text {tabel }}=$ valid

Rumus Dasar $\mathrm{r}_{\text {tabel }}$ adalah:

$$
r=\frac{t}{\sqrt{d f+t^{2}}}
$$

Keterangan:

$\mathrm{R}=$ Nilai $\mathrm{r}$ tabel

$\mathrm{T}=$ Nilai $\mathrm{t}$ tabel

Df $=$ Degree of freedom

Dalam penelitian ini uji validitas, digunakan untuk mengetahui nilai signifikansi dengan membandingkan nilai $r_{\text {hitung }}$ dengan $r_{\text {tabel }}$ untuk degree of freedom $(\mathrm{df})=n-k$, dimana simbol $k$ dalam hal ini $\mathrm{n}$ adalah jumlah sampel, pada kasus ini jumlah sampel (n) adalah 106 responden. Adapun perhitungan besarnya df adalah $\mathrm{df}=106-17=89$, dan alpha 0,05 maka didapatkan $\mathrm{r}$ tabel $=0,206$. 
Citec Journal, Vol. 1, No. 2, Februari 2014 - April 2014

Tabel 2. Hasil Data Uji Validitas

\begin{tabular}{|c|c|c|c|}
\hline No & Pertanyaan & $\begin{array}{c}\mathbf{R} \\
\text { Hitung }\end{array}$ & Keterangan \\
\hline & Pendidikan & & \\
\hline 1 & $\begin{array}{l}\text { Apakah Saudara setuju Biaya Kuliah menjadi bahan } \\
\text { pertimbangan dalam memilih STIKES? }\end{array}$ & 0,550 & Valid \\
\hline 2 & $\begin{array}{l}\text { Apakah saudara setuju Biaya Kos menjadi bahan } \\
\text { pertimbangan dalam memilih STIKES? }\end{array}$ & 0,277 & Valid \\
\hline 3 & $\begin{array}{l}\text { Apakah saudara setuju Biaya Transportasi menjadi bahan } \\
\text { pertimbangan dalam memilih STIKES? }\end{array}$ & 0,437 & Valid \\
\hline \multirow[t]{2}{*}{4} & $\begin{array}{l}\text { Apakah saudara setuju Biaya Hidup menjadi bahan } \\
\text { pertimbangan dalam memilih STIKES? }\end{array}$ & 0,418 & Valid \\
\hline & Reputasi & & \\
\hline 5 & $\begin{array}{l}\text { Apakah saudara setuju Alumni Mudah mencari kerja } \\
\text { termasuk dalam pertimbangan dalam memilih STIKES? }\end{array}$ & 0,520 & Valid \\
\hline 6 & $\begin{array}{l}\text { Apakah Saudara setuju Memiliki kerjasama dengan pihak } \\
\text { rumah sakit negeri maupun swasta termasuk dalam } \\
\text { pertimbangan memilih STIKES? }\end{array}$ & 0,526 & Valid \\
\hline 7 & $\begin{array}{l}\text { Apakah Saudara setuju Penghargaan yang diperoleh pihak } \\
\text { kampus termasuk dalam pertimbangan memilih STIKES? }\end{array}$ & 0,526 & Valid \\
\hline \multirow[t]{2}{*}{8} & $\begin{array}{l}\text { Apakah Saudara setuju Fasilitas Pendidikan termasuk } \\
\text { dalam pertimbangan memilih STIKES? }\end{array}$ & 0,602 & Valid \\
\hline & Sarana Dan Prasarana & & \\
\hline 9 & $\begin{array}{l}\text { Apakah Saudara setuju Memiliki ruang kuliah berac dan } \\
\text { memadai termasuk dalam pertimbangan memilih STIKES? }\end{array}$ & 0,605 & Valid \\
\hline 10 & $\begin{array}{l}\text { Apakah Saudara setuju Memilki fasilitas laboratorium } \\
\text { yang lengkap termasuk dalam pertimbangan memilih } \\
\text { STIKES? }\end{array}$ & 0,713 & Valid \\
\hline 11 & $\begin{array}{l}\text { Apakah Saudara setuju Memiliki rumah sakit sendiri } \\
\text { termasuk pertimbangan dalam pertimbangan memilih } \\
\text { STIKES? }\end{array}$ & 0,663 & Valid \\
\hline 12 & $\begin{array}{l}\text { Apakah Saudara setuju Memilki gedung sendiri termasuk } \\
\text { dalam pertimbangan memilih STIKES? }\end{array}$ & 0,657 & Valid \\
\hline 13 & $\begin{array}{l}\text { Apakah Saudara setuju Status Akreditasi Kampus menjadi } \\
\text { bahan pertimbangan dalam memilih STIKES? }\end{array}$ & 0,569 & Valid \\
\hline 14 & $\begin{array}{l}\text { Apakah saudara setuju Kualitas dan Kuantitas Dosen } \\
\text { menjadi bahan pertimbangan dalam memilih STIKES? }\end{array}$ & 0,674 & Valid \\
\hline 15 & $\begin{array}{l}\text { Apakah saudara setuju Lokasi Kampus menjadi bahan } \\
\text { pertimbangan dalam memilih STIKES? }\end{array}$ & 0,705 & Valid \\
\hline 16 & $\begin{array}{l}\text { Apakah saudara setuju Jarak Sekolah Tinggi Dengan } \\
\text { Tempat Tinggal menjadi bahan pertimbangan dalam } \\
\text { memilih STIKES? }\end{array}$ & 0,519 & Valid \\
\hline 17 & $\begin{array}{l}\text { Apakah saudara setuju Beasiswa yang ditawarkan pihak } \\
\text { STIKES menjadi bahan pertimbangan dalam memilih } \\
\text { STIKES? }\end{array}$ & 0,631 & Valid \\
\hline
\end{tabular}


Pada Tabel 2 hasil uji validitas diatas dapat diambil kesimpulan bahwa nilai dari tiap instrument pertanyaan dari semua variabel adalah valid. Sehingga dapat digunakan sebagai sampel kriteria dalam penelitian ini.

Berikut data kriteria yang digunakan dalam penelitian ini;

1. Pendidikan /K1 terdiri dari: a) Biaya Kuliah (B1),b) Biaya Kos (B2),c) Biaya Transportasi (B3),d) Biaya Hidup (B4).

2. Reputasi /K2 terdiri dari: a) Alumni Mudah Mencari Kerja (R1),b) Memiliki Kerjasama (R2), c) Penghargaan (R3), d) Fasilitas Pendidikan (R4).

3. Sarana dan Prasarana /K3 terdiri dari: a) Ruang Kuliah Memadai dan ber ac (S1), b) Laboraturium (S2), c) Rumah sakit (S3), d) Gedung sendiri (S4).

4. Akreditasi/K4.

5. Kualitas dan Kuantitas Dosen (KKD) /K5.

6. Lokasi Kampus /K6.

7. Jarak Kampus/K7.

8. Beasiswa /K8.

\subsection{Analisa Matriks SWOT}

Pada Gambar 2 menggambarkan analisis matrix SWOT dalam merancang prototipe sistem pendukung keputusan dalam memilih sekolah tinggi ilmu kesehatan dan dapat membantu menentukan kebutuhan fungsional.

\begin{tabular}{|c|c|c|c|}
\hline & IFAS & \multirow{2}{*}{$\begin{array}{l}\text { STRENGTHS (S) } \\
\text { - Aplikasi sistem pendukung keputusan berbasis } \\
\text { website, sehingga bisa diakses kapan saja tidak } \\
\text { terbatas wakttu, tempat dan jaral }\end{array}$} & \multirow{2}{*}{$\begin{array}{l}\text { WEAKNESSES (W) } \\
\text { - Membutuhlan akses intemet yang stabil. }\end{array}$} \\
\hline \multirow{2}{*}{\multicolumn{2}{|c|}{ EFAS }} & & \\
\hline & & $\begin{array}{l}\text { - Perhitungan ranking den pengecelkan konsistensi } \\
\text { antara kriteria secara otomatis oleh sistem. }\end{array}$ & $\begin{array}{l}\text { - Membutuhlsan kasktifan dari user dalam } \\
\text { mengupdate data }\end{array}$ \\
\hline OPPORTUNIES & & STRATEGISO & STRATEGIWO \\
\hline $\begin{array}{l}\text { - Antusias minat mahasiswa dalam memilih selkolah tinggi } \\
\text { ilmu kesehatan sangat tinggi. }\end{array}$ & & $\begin{array}{l}\text { - Menggunaksan desian antar mulka yang } \\
\text { mudah dipahami. }\end{array}$ & $\begin{array}{l}\text { Meningkatkan pemanfastan } \\
\text { telnologi berbasis web yang ada }\end{array}$ \\
\hline $\begin{array}{l}\text { Perkembangan telnologi berbasis web semalkin pesat, } \\
\text { memungkinkan untulk mengembanglan aplikasi DSS } \\
\text { berbasis web. }\end{array}$ & & $\begin{array}{l}\text { - Meningkatkan pengembangan aplikasi } \\
\text { untul memenuhi kebutuhan pengguna }\end{array}$ & $\begin{array}{l}\text { - Meninglsatkan pelasyanan aplikasi } \\
\text { sgar dapat mengurangi kealtifan } \\
\text { user. }\end{array}$ \\
\hline $\begin{array}{l}\text { - Banyalnya disedialsan akses intemet murah bahksan } \\
\text { gratis,sehingga memudahkan dalam mengalksesnya. }\end{array}$ & & & \\
\hline $\begin{array}{l}\text { - Saat ini belum ada splikasi khusus dalam memilh selkolsh } \\
\text { tinggi ilmu kesehatan terutama di Yogyalkarts. }\end{array}$ & & & \\
\hline THREATHS (T) & & STRATEGIST & STRATEGIWT \\
\hline - Jaringan Intemet yang terputus. & & $\begin{array}{l}\text { - Menggunakan server hosting dari Indonesia, agar } \\
\text { akses jaringan stabil dan server tidak mudah hang } \\
\text { serta mudah dialkses }\end{array}$ & $\begin{array}{l}\text { - Mengurangi proses yang berada } \\
\text { server }\end{array}$ \\
\hline - Server hang, sehingga website tidak bisa diakses. & & & \\
\hline
\end{tabular}

Gambar 2. Matrix SWOT

\subsection{Kebutuhan Fungsional}

Kebutuhan fungsional sistem ini adalah jenis kebutuhan yang berisi proses-proses apa saja yang dilakukan oleh sistem.1) Pengguna atau user sistem adalah calon mahasiswa.2) Sebelum masuk keaplikasi utama user diwajibkan daftar terlebih.3) Sesudah daftar user diwajibkan login.4) Sistem dapat menolak ketika username atau password yang dimasukan salah atau belum terdaftar.5) User dapat melihat dan memilih data STIKES.6) User dapat memasukkan perbandingan matrix berpasangan.7) Sistem dapat melakukan secara otomatis perhitungan perbandingan matrix berpasangan.8) Sistem dapat melakukan pengecekkan secara otomatis terhadap konsistensi antara kriteria maupun subkriteria yang digunakan.9) Sistem dapat menambah nilai STIKES berdasarkan kriteria dan subkriteria.10) Sistem dapat melakukan proses perhitungan perangkingan secara otomatis dan menampilkan data hasil perangkingan.11) Sistem dapat logout. 


\subsection{Arsitektur Prototipe}

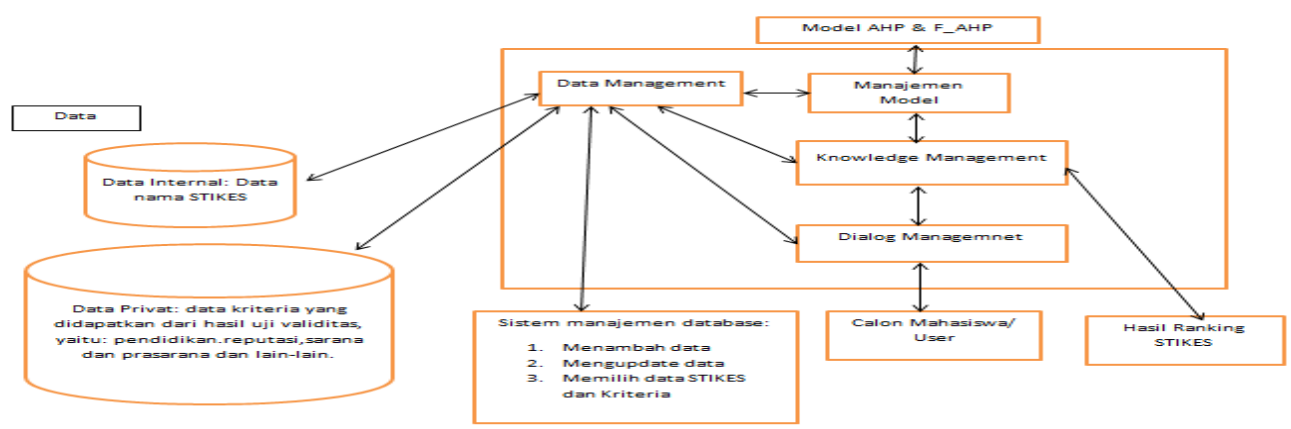

Gambar 3. Arsistektur Prototipe Perancangan Sistem pendukung Keputusan Dalam Memilih STIKES

Pada gambar 3 Arsitektur prototipe yang menggambarkan perancangan sistem pendukung keputusan dalam memilih sekolah tinggi ilmu kesehatan (STIKES) yang terdiri dari:1) data: internal dan privat.2)Data management: sistem manajemen database.3)Manajemen Model:Model AHP dan FUZZY AHP.4)Dialog Management:Calon Mahasiswa/User.5) knowledge Management:Hasil Ranking STIKES.

\subsection{Analisis Pengolahan Metode AHP}

Model AHP (Analytical Hierarchi Process) adalah sebuah hierarki fungsional dengan input utamanya persepsi manusia [4].

Langkah-langkah Perhitungan dalam metode AHP meliputi [4]: 1) Mendefinisikan masalah dan menentukan solusi yang diinginkan, lalu menyusun herarki dari permasalahan yang dihadapi. 2) Menentukan prioritas elemen: a) Membuat perbandingan pasangan yaitu membandingkan elemen secara berpasangan sesuai kriteria yang diberikan.b) Matriks perbandingan berpasangan diisi menggunakan bilangan untuk merepresentasikan kepentingan relative dari suatu elemen terhadap elemen lainnya. 3) Sintesis yaitu dilakukan pertimbangan terhadap perbandingan berpasangan di sintesis untuk memperoleh keseluruhan prioritas. Langkahnya adalah: a) Menjumlahkan nilai-nilai dari setiap kolom matriks. b) Membagi setiap nilai dari kolom dengan total kolom yang bersangkutan untuk memperoleh normalisasi matriks. c) Menjumlahkan nilai-nilai dari setiah baris dan membaginya dengan jumlah elemen untuk mendapatkan nilai rata-rata.

Berikut contoh perhitungan menggunakan AHP :

Tabel 3. Perbandingan matrix kriteria utama

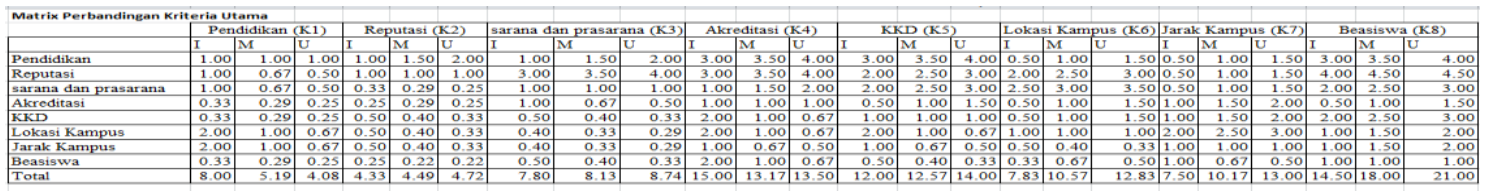

Tabel 3.Perbandingan matrix kriteria utama yang dimana nilai matrix tersebut diinputkan oleh user, perhitungan selanjutkan dibanding per 1 setiap nilai matrix kriteria utamanya dan dihitung jumlah perbaris kriterianya. 
Tabel 4. Matrix nilai kriteria utama

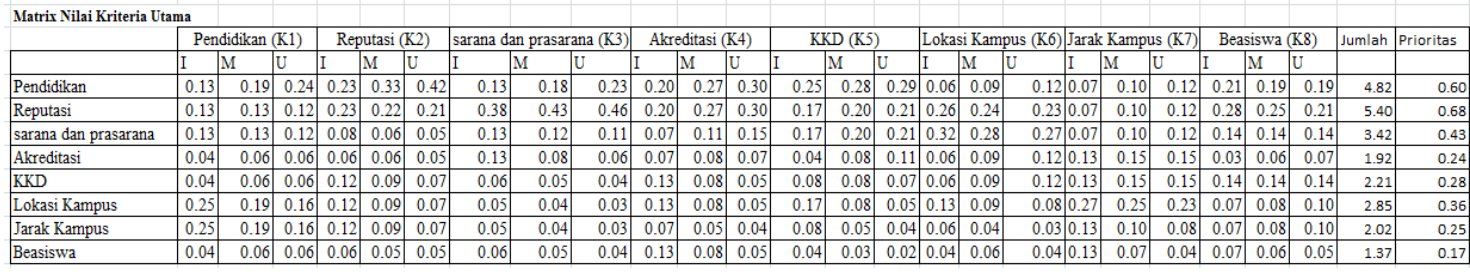

Pada tabel 4. matrik ini kolom pendidikan dan baris pendidikan (0.125) didapatkan dari nilai kolom KKD baris KKD kolom [I] dibagi dengan nilai total baris kolom [I] jumlah pada kolom pendidikan pada tabel 3., proses ini dikerjakan sampai pada kolom Beasiswa baris Beasiswa. Sedangkan jumlah merupakan penjumlahan dari seluruhan baris perkriteria. Untuk nilai pada kolom prioritas diperoleh dari nilai pada kolom jumlah dibagi dengan jumlah kriteria, dalam penelitian ini ada 8 kriteria utama.

Tabel 5. Penjumlahan setiap baris kriteria utama

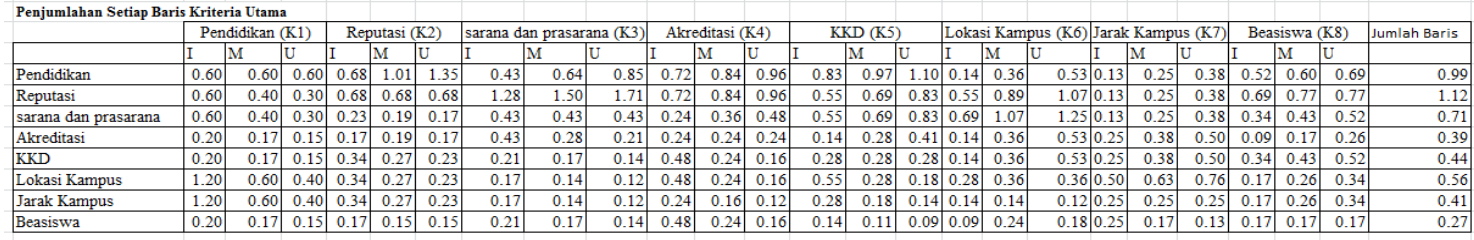

Pada table 5, penjumlahan nilai matrix setiap baris didapatkan dari perkalian nilai prioritas pada tabel 4 . dengan matrik perbandingan berpasangan pada tabel 3 , contoh pada tabel 4 kolom prioritas Baris pendidikan dikalikan nilai baris pendidikan kolom [i] pada tabel 3. dan untuk Jumlah Baris (B) pada tabel 4. didapatkan pada penjumlahan setiap baris perkriteria dibagi jumlah dua kali lipat kriteria.

Tabel 6. Rasio konsistensi kriteria utama

\begin{tabular}{|l|r|r|r|}
\hline \multicolumn{1}{|c|}{ Kriteria } & \multicolumn{1}{c|}{ Jumlah Baris } & \multicolumn{1}{c|}{ Prioritas } & \multicolumn{1}{c|}{ Hasil } \\
\hline Pendidikan & 0.985451092 & 0.602012858 & 1.587 \\
\hline Reputasi & 1.118828585 & 0.675239629 & 1.794 \\
\hline sarana dan prasarana & 0.710578274 & 0.427429983 & 1.138 \\
\hline Akreditasi & 0.387727993 & 0.239519756 & 0.627 \\
\hline KKD & 0.439957828 & 0.275888122 & 0.716 \\
\hline Lokasi Kampus & 0.563539795 & 0.35618706 & 0.92 \\
\hline Jarak Kampus & 0.40752131 & 0.252015468 & 0.66 \\
\hline Beasiswa & 0.269151761 & 0.171707125 & 0.441 \\
\hline & & Total & $\mathbf{7 . 4 4 2}$ \\
\hline Jumlah dari nilai-nilai hasil & & & 7.44 \\
\hline $\mathrm{n}($ jumlah kriteria) & & & 8 \\
\hline$\lambda$ maks (jumlah/n) & & & 0.9302 \\
\hline CI $((\lambda$ maks $-\mathrm{n}) /(\mathrm{n}-1))$ & & & -1.01 \\
\hline CR $(\mathrm{CI} / \mathrm{IR})$ & & & $\mathbf{- 0 . 6 5}$ \\
\hline
\end{tabular}

Pada tabel 6. Jika nilai CR lebih dari 10\%, maka penilaian data judgment harus diperbaiki, namun jika rasio konsistensi (CI/IR) kurang atau sama dengan 0,1, maka hasil perhitungan bisa dinyatakan benar.

Menggunakan proses perhitungan yang sama untuk menghitung subkriteria npendidikan,reputasi dan sarana dan prasarana., yaitu proses perhitungan dari tabel 3-6. 


\subsection{Analisis Pengolahan Metode Fuzzy AHP}

Metode Fuzzy AHP merupakan Pendekatan yang memberikan keuntungan dalam menangkap ketidakjelasan pendapat manusia dan memecahkan masalah penelitian melalui cara yang terstruktur dan proses yang sederhana [8].

Langkah penyelesaian Fuzzy AHP adalah sebagai berikut [9]:

1. Membuat struktur hierarki masalah yang akandiselesaikan dan menentukan perbandingan matriks berpasangan antar kriteria dengan skala TFN (Tringular Fuzzy Number).

2. Menentukan nilai sistesis fuzzy (Si) prioritas dengan rumus:

$$
S i=\sum_{j=1}^{m} M_{i}^{j} \mathrm{x} \frac{1}{\sum_{i=1}^{n} \sum_{j=1}^{\mathrm{m}} \mathrm{M}_{i}^{j}}
$$

3. Menentukan nilai vektor (V) dan nilai Ordinat Defuzzifikasi (d').Untuk $k=1,2, \ldots n ; k \neq i$, maka diperoleh nilai bobot vektor: $W^{\prime}=\left(d^{\prime}\left(A_{1}\right), d^{\prime}\left(A_{2}\right), \ldots, d^{\prime}\left(A_{n}\right)\right)^{T}$

4. Normalisasi nilai bobot vektor fuzzy (W= Nilai bobot vektor yang ternormalisasi adalah rumus berikut: $\mathrm{W}=\left(\mathrm{d}\left(\mathrm{A}_{1}\right), \mathrm{d}\left(\mathrm{A}_{2}\right), \ldots, \mathrm{d}\left(\mathrm{A}_{\mathrm{n}}\right)\right)^{\mathrm{T}}$

5. Dimana $\mathrm{W}$ adalah bilangan non fuzzy.

Perumusan normalisasinya adalah: $d\left(A_{n}\right)=\frac{d^{\prime}}{\sum_{i=1}^{n} d^{\prime}\left(A_{n}\right)}$

Adapun contoh perhitungan dari fuzzy AHP adalah :

Tabel 7. Perbandingan Matrix antar kriteria utama

\begin{tabular}{|c|c|c|c|c|c|c|c|c|c|c|c|c|c|c|c|c|c|c|c|c|c|c|c|c|c|c|c|}
\hline & \multicolumn{3}{|c|}{ Pendidikan (K1) } & \multicolumn{3}{|c|}{ Reputasi (K2) } & \multicolumn{3}{|c|}{ sarana dan prasarana $(\mathrm{K} 3)$} & \multicolumn{3}{|c|}{ Akreditasi (K4) } & \multicolumn{3}{|c|}{$\mathrm{KKD}(\mathrm{K} 5)$} & \multicolumn{3}{|c|}{ Lokasi Kampus (K6) } & \multicolumn{3}{|c|}{ Jarak Kampus (K7) } & \multicolumn{3}{|c|}{ Beasiswa (K8) } & \multicolumn{3}{|c|}{ Jumlah baris } \\
\hline & I & M & $\mathrm{U}$ & $\mathrm{I}$ & $\mathrm{M}$ & $\mathrm{U}$ & I & $\mathrm{M}$ & $\mathrm{U}$ & I & M & $\mathrm{U}$ & I & M & $\mathrm{U}$ & \begin{tabular}{l|l} 
& 1 \\
$I$
\end{tabular} & \begin{tabular}{l|l} 
& \\
\end{tabular} & $\mathrm{U}$ & \begin{tabular}{|l|ll} 
I & A
\end{tabular} & \begin{tabular}{l|l}
$\mathrm{M}$ & $\mathrm{i}$
\end{tabular} & \begin{tabular}{|l|l|l}
$\mathrm{U}$ & $\mathrm{I}$
\end{tabular} & I & M & $\mathrm{U}$ & I & \begin{tabular}{|l|l}
$\mathrm{M}$ & $\mathrm{T}$
\end{tabular} & $\mathrm{U}$ \\
\hline Pendidikan & 1.00 & 1.00 & 1.00 & 1.00 & 1.50 & 2.00 & 1.00 & 1.50 & 2.00 & 3.00 & 3.50 & 4.00 & 3.00 & 3.50 & 4.00 & 0.50 & 1.00 & 1.50 & 0.50 & 1.00 & 1.50 & 3.00 & 3.50 & 4.00 & 13.00 & 16.50 & 20.00 \\
\hline Reputasi & 1.00 & 0.67 & 0.50 & 1.00 & 1.00 & 1.00 & 3.00 & 3.50 & 4.00 & 3.00 & 3.50 & 4.00 & 2.00 & 2.50 & 3.00 & 2.00 & 2.50 & 3.00 & 0.50 & 1.00 & 1.50 & 4.00 & 4.50 & 4.50 & 16.50 & \begin{tabular}{|c|}
19.17 \\
\end{tabular} & 21.50 \\
\hline sarana dan prasarana & 1.00 & 0.67 & 0.50 & 0.33 & 0.29 & 0.25 & 1.00 & 1.00 & 1.00 & 1.00 & 1.50 & 2.00 & 2.00 & 2.50 & 3.00 & 2.50 & 3.00 & 3.50 & 0.50 & 1.00 & 1.50 & 2.00 & 2.50 & 3.00 & 10.33 & 12.45 & 14.75 \\
\hline Akreditasi & 0.33 & 0.29 & 0.25 & 0.25 & 0.29 & 0.25 & 1.00 & 0.67 & 0.50 & 1.00 & 1.00 & 1.00 & 0.50 & 1.00 & 1.50 & 0.50 & 1.00 & 1.50 & 1.00 & 1.50 & 2.00 & 0.50 & 1.00 & 1.50 & 5.08 & 6.74 & 8.50 \\
\hline KKD & 0.33 & 0.29 & 0.25 & 0.50 & 0.40 & 0.33 & 0.50 & 0.40 & 0.33 & 2.00 & 1.00 & 0.67 & 1.00 & 1.00 & 1.00 & 0.50 & 1.00 & 1.50 & 1.00 & 1.50 & 2.00 & 2.00 & 2.50 & 3.00 & 7.83 & 8.09 & 9.08 \\
\hline Lokasi Kampus & 2.00 & 1.00 & \begin{tabular}{|l|}
0.67 \\
\end{tabular} & 0.50 & 0.40 & 0.33 & 0.40 & 0.33 & 0.29 & 2.00 & 1.00 & 0.67 & 2.00 & 1.00 & 0.67 & 1.00 & 1.00 & 1.00 & 2.00 & 2.50 & 3.00 & 1.00 & 1.50 & 2.00 & 10.90 & 8.73 & 8.62 \\
\hline Jarak Kampus & 2.00 & 1.00 & 0.67 & 0.50 & 0.40 & 0.33 & 0.40 & 0.33 & 0.29 & 1.00 & 0.67 & 0.50 & 1.00 & 0.67 & 0.50 & 0.50 & 0.40 & 0.33 & 1.00 & 1.00 & 1.00 & 1.00 & 1.50 & 2.00 & 7.40 & 5.97 & 5.62 \\
\hline Beasiswa & 0.33 & 0.29 & 0.25 & 0.25 & 0.22 & 0.22 & 0.50 & 0.40 & 0.33 & 2.00 & 1.00 & 0.67 & 0.50 & 0.40 & & 0.33 & 0.67 & 0.50 & 1.00 & 0.67 & 0.50 & 1.00 & 1.00 & 1.00 & 5.92 & 4.64 & 3.81 \\
\hline & & & & & & & & & & & & & & & & & & Total & & & & & & & 76.97] & 82.28 & 91.88 \\
\hline
\end{tabular}

Pada Tabel 7. Nilai Jumlah baris dan total didapatkan dari penjumlahan setiap baris kriteria, contoh jumlah baris [i] didapat dari semua kolom [i] perkriteria.

Tabel 8. Sintensis Kriteria Utama

\begin{tabular}{|l|l|l|l|}
\hline \multicolumn{4}{|c|}{ Nilai Sintesis Fuzzy (Kriteria Utama) } \\
\hline \multicolumn{1}{|l|}{ SK1= } & $\begin{array}{l}\text { perkalian } \\
\text { masing-masing }\end{array}$ & & \\
\hline x (1/total berbaris) & $\mathbf{0 . 0 1}$ & $\mathbf{0 . 0 1}$ & $\mathbf{0 . 0 1}$ \\
\hline K1 & 0.17 & 0.20 & 0.22 \\
\hline K2 & 0.21 & 0.23 & 0.23 \\
\hline K3 & 0.13 & 0.15 & 0.16 \\
\hline K4 & 0.07 & 0.08 & 0.09 \\
\hline K5 & 0.10 & 0.10 & 0.10 \\
\hline K6 & 0.14 & 0.11 & 0.09 \\
\hline K7 & 0.10 & 0.07 & 0.06 \\
\hline K8 & 0.08 & 0.06 & 0.04 \\
\hline
\end{tabular}


A. Penentuan vektor (v) dan nilai ordinat defuzzifikasi kriteria utama

$$
\begin{array}{ll}
\text { K1 }\{1,-0.20,-1.8,-2.1,-3.9,-5.3,-7.7\} & =-7,7 \\
\text { K2 }\{0.1,-1.9,-4.2,-6.0,-19.3,-21.2,-48.5\} & =\mathbf{- 4 8 , 5} \\
\text { K3 }\{2,5,-1.5,-2.0,-7.4,-12.8,-44.3\} & =\mathbf{- 4 4 , 3} \\
\text { K4 }\{4,9,3,1,7,-1.1,-28.8\} & =\mathbf{2 8 , 8} \\
\text { K5 }\{8,-54.3,-10.3,-1.3,0,2,3\} & =\mathbf{- 5 4 , 3} \\
\text { K6 }\{-4.1,-2.7,-0.8,1,0,1,1\} & =-\mathbf{4 , 1} \\
\text { K7 }\{-18.8,-6.1,-4.5,0,-0.1,0,1\} & =\mathbf{1 8 , 8} \\
\text { K8 }\{-42.5,-8.1,-7.4,-1.5,-1.1,-0.5,0.04\} & =-42,5
\end{array}
$$

Hasil Persamaan $=-\{-7,7,-48,5,-44,3,-28,8,-54,3,-4.1,-18,8,-42,5\}$

Nilai persamaan kriteria K1 didapatkan dari hasil perbandingan antara kriteria K1 sampai K8 untuk mendapat nilai terkecil, setelah didapatkan nilai terkecil setiap perbandingan kriteria dibuatlah persamaan.

B. Normalisasi kriteria utama

Persamaan

Total Persamaan

Normalisasi

$$
=(-7,7+-48,5+-44,3+-28,8+-54,3+-4,1+-18,8+42,5)
$$$$
=
$$$$
-249,04
$$$$
=\{0,03+0,19+0,18+0,11+0,22+0,002+0,007+0,17\}=1
$$

Nilai Normalisasi tersebutkan yang akan diambil menjadi bobot perkriteria utama, sedangkan untuk mendapatkan bobot subkriteria pendidikan,reputasi dan sarana dan prasarana, sama seperti proses perhitungan mendapatkan bobot kriteria utama.

Tabel 9. Kriteria Penilaian

\begin{tabular}{|l|c|}
\hline \multicolumn{2}{|c|}{ Kriteria Penilaian,umum,Jarak,Letak } \\
\hline Buruk/Sangat Jauh/Tidak Stratregis & 1 \\
\hline Cukup/Jauh/Cukup Strategis & 2 \\
\hline Baik/Dekat/Strategis & 3 \\
\hline Baik Sekali/Sangat Dekat/Sangat Strategis & 4 \\
\hline
\end{tabular}

Pada Tabel 9 penilaian kriteria berdasarkan kategori kriteria. Kecuali untuk perhitungan biaya menggunakan rumus. Nilai biaya=Jumlah biaya $*$ (total kampus/nilai tertinggi). 
Citec Journal, Vol. 1, No. 2, Februari 2014 - April 2014

Tabel 10. Penilaian Kampus Perkriteria

\begin{tabular}{|l|r|r|r|}
\hline \multicolumn{1}{|c|}{ Kriteria } & \multicolumn{3}{|c|}{ Kampus } \\
\hline & A & \multicolumn{1}{|c|}{ B } & \multicolumn{1}{c|}{ C } \\
\hline Pendidikan (K1) & \multicolumn{3}{|c|}{} \\
\hline B1 & 3 & 2.35 & 1.0338346 \\
\hline B2 & 3 & 2 & 2.5 \\
\hline B3 & 3 & 2.4 & 18 \\
\hline B4 & 3 & 2.4 & 9 \\
\hline Reputasi (K2) & \multicolumn{3}{|c|}{} \\
\hline R1 & 3 & 3 & 4 \\
\hline R2 & 4 & 3 & 4 \\
\hline R3 & 2 & 1 & 3 \\
\hline R4 & 4 & 3 & 3 \\
\hline Sarana dan Prasarana & \multicolumn{3}{|c|}{} \\
(K3) & 4 & 4 & 2 \\
\hline s1 & 3 & 3 & 1 \\
\hline S2 & 3 & 3 & 3 \\
\hline S3 & 4 & 4 & 3 \\
\hline S4 & 3 & 3 & 4 \\
\hline Akreditasi (K4) & 3 & 3 & 2 \\
\hline KKD(K5) & 4 & 4 & 1 \\
\hline Lokasi Kampus (K6) & 4 & 4 & 1 \\
\hline Jarak Kampus (K7) & 2 & 3 & 1 \\
\hline Beasiswa (K8) & \multicolumn{3}{|c|}{} \\
\hline
\end{tabular}

Tabel 10. adalah table penilaian setiap kampus berdasarkan kriteria, yang nilai dinputkan oleh user .

Tabel 11. Perhitungan Matrix Alternatif Kriteria Beasiswa

\begin{tabular}{|l|r|l|r|l|r|}
\hline Beasiswa & \multicolumn{1}{|l|}{ A } & B & C & Jumlah & Normalisasi \\
\hline A & 1 & 0.667 & 2 & 3.66667 & 0.393 \\
\hline B & 0.667 & 1 & 3 & 4.66667 & 0.5 \\
\hline C & 0.5 & 0.333 & 1 & 1.83333 & 0.196 \\
\hline & & & Total & 10.1667 & \\
\hline
\end{tabular}

Tabel 11 adalah salah satu contoh Matrix perbandingan alternatif kriteria Beasiswa, yang dimana membandingkan nilai kampus A,B,C. contoh nilai baris A kolom B $(0,667)$ didapatkan dari nilai kampus A (2) dibagi nilai kampus B (3).

Tabel 12 .Hasil Perangkingan

\begin{tabular}{|c|c|c|c|c|c|c|c|c|c|c|c|c|c|c|c|c|c|c|c|}
\hline Global & \multicolumn{4}{|c|}{ Pendidikan } & \multicolumn{4}{|c|}{ Reputasi } & \multicolumn{4}{|c|}{ Sarana } & Akreditasi & KKD & Lokasi & Jarak & Beasiswa & Bobot Global & Ranking \\
\hline & \multicolumn{4}{|c|}{0.030772404} & \multicolumn{4}{|c|}{0.19459671} & \multicolumn{4}{|c|}{0.178244981} & 0.11538862 & 0.21814 & 0.01667 & 0.07537164 & \begin{tabular}{|l|l|} 
& 0.17082 \\
\end{tabular} & & \\
\hline & $B 1$ & \begin{tabular}{|l|l}
$B 2$ & $B$ \\
\end{tabular} & B3 & B4 & R1 & R2 & $R 3$ & R4 & s1 & 52 & 53 & 54 & & & & & & & \\
\hline Bobot w & \begin{tabular}{|l|}
0.816883 \\
\end{tabular} & \begin{tabular}{|l|}
-0.13 \\
\end{tabular} & \begin{tabular}{|l|l|}
0.019493 \\
\end{tabular} & 0.0194927 & 0.070020228 & 0.09 & 0.831605 & 0.00955 & 0.6787791 & \begin{tabular}{l|l|}
1 & 0.28 \\
\end{tabular} & 0.232659 & \begin{tabular}{|l|l|}
0.196168015 \\
\end{tabular} & & & & & & & \\
\hline \begin{tabular}{|l|} 
Alternatif \\
\end{tabular} & & & & & & & & & & & & & & & & & & & \\
\hline$A$ & 0.554852 & 0.396 & \begin{tabular}{|l|}
0.258929 \\
\end{tabular} & 0.2767857 & 0.294642857 & 0.36 & 0.25 & 0.39286 & 0.4285714 & \begin{tabular}{l|l|}
4 & 0.54 \\
\end{tabular} & 0.321429 & 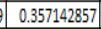 & 0.42857143 & 0.375 & \begin{tabular}{|l|l|}
0.64286 \\
\end{tabular} & 0.30803571 & \begin{tabular}{l|l|} 
& 0.39286 \\
\end{tabular} & 1.947847348 & 2 \\
\hline$B$ & 0.434564 & 0.264 & 0.207143 & 0.2214286 & \begin{tabular}{|l|l|} 
& 0.357142857 \\
\end{tabular} & 0.27 & 0.375 & 0.29464 & 0.4285714 & \begin{tabular}{|l|l|}
4 & 0.54 \\
\end{tabular} & 0.321429 & \begin{tabular}{l|l|l|l|l|l}
9 & 0.357142857
\end{tabular} & 0.42857143 & 0.375 & 0.24107 & \begin{tabular}{|l|l|}
0.30803571 \\
\end{tabular} & $\begin{array}{ll} & 0.5 \\
\end{array}$ & 1.953310025 & 1 \\
\hline$c$ & 0.191208 & \begin{tabular}{|l|l|} 
& 0.33 \\
\end{tabular} & $\mid 1.392857$ & 0.8303571 & 0.330357143 & 0.36 & 0.375 & 0.29464 & 0.2142857 & \begin{tabular}{l|l|}
7 & 0.18 \\
\end{tabular} & 0.321429 & \begin{tabular}{|l|l|}
9 & 0.267857143 \\
\end{tabular} & \begin{tabular}{|c|c|} 
\\
\end{tabular} & 0.25 & 0.16071 & 0.35204082 & \begin{tabular}{|l|l|} 
& 0.19643 \\
\end{tabular} & 1.36913925 & 5 \\
\hline
\end{tabular}

Berdasarkan Tabel 12 dilihat dari hasil bobot global dapat diambil kesimpulan bahwa yang mendapatkan ranking pertama adalah kampus B dengan hasil nilai bobot global 1,95 dan disusul yang menduduki ranking kedua Kampus A dengan hasil bobot global 1,94 selanjutnya 
yang berada diranking ketiga adalah Kampus $\mathrm{C}$ dengan hasil Bobot 1,36. Hasil perhitungan bobot global merupakan kalkulasi antara kriteria utama dan subkriteria dengan nilai alternatif.

\subsection{Perancangan Sistem}

Dalam penelitian ini penulis menggunakan UML yaitu sebagai berikut:

a. Use Case Diagram

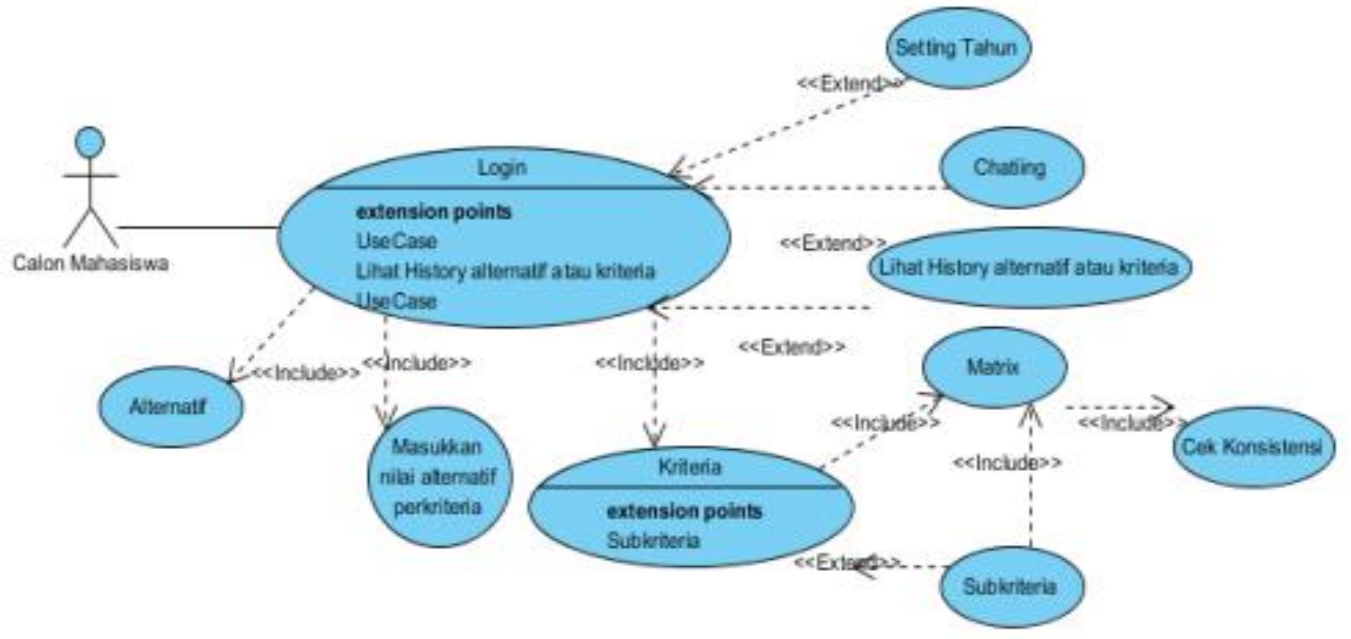

Gambar 4. Use Case Diagram

Pada Gambar 4. Use case diagram yang menggambarkan aktivitas yang akan dilakukan oleh actor yaitu calon mahasiswa

b. Sequence Diagram

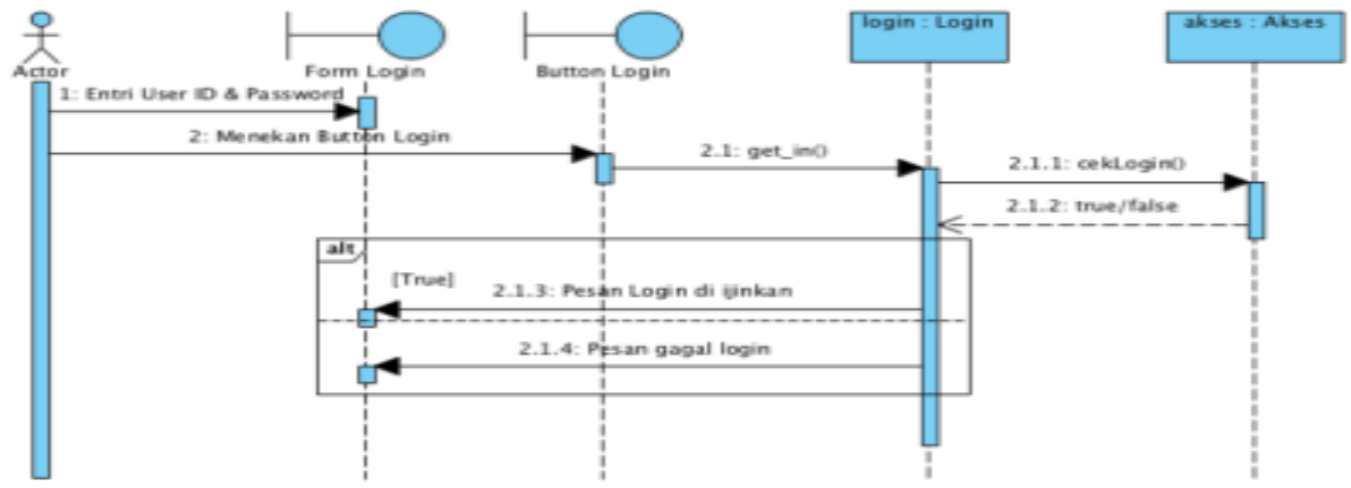

Gambar 5.Sequence Diagram Login

Pada Gambar 5 Sequence diagram yang menggambarkan proses message diagram khusus $\operatorname{login}$ 
Citec Journal, Vol. 1, No. 2, Februari 2014 - April 2014

c. Activity Diagram

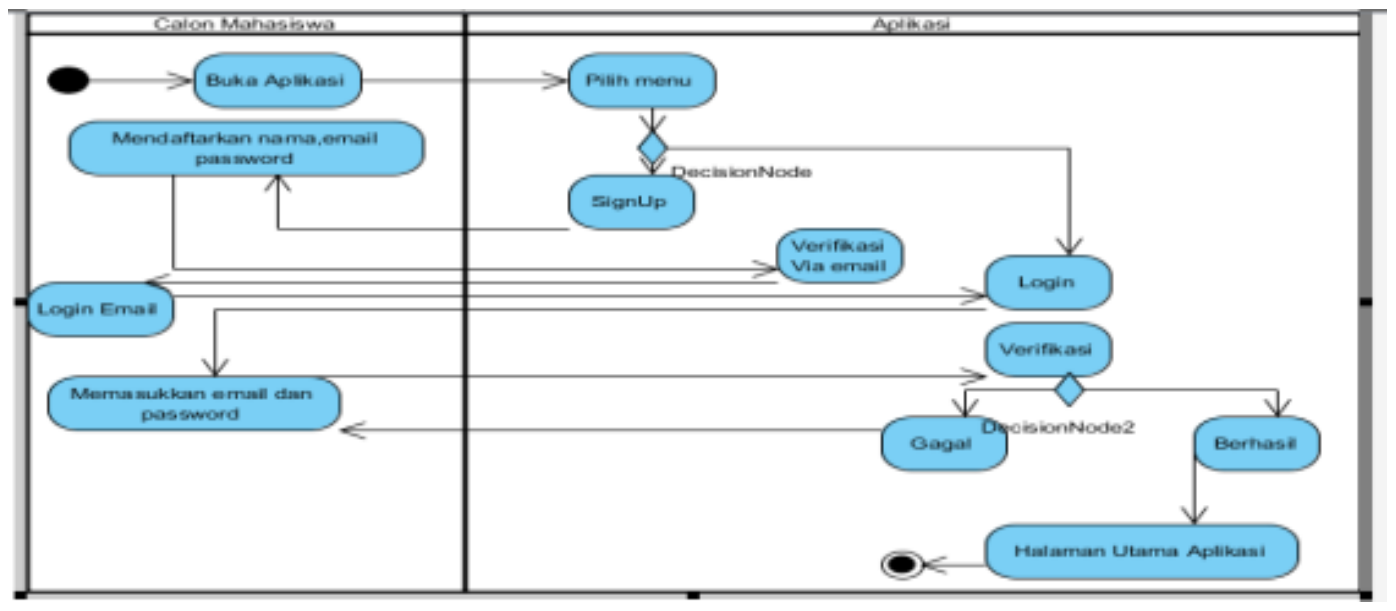

Gambar 6. Activiy Diagram Login

Pada Gambar 6. Activity diagram yang menggambarkan proses aktivitas apa saja yang dilakukan calon mahasiswa untuk login.

\subsection{Hasil Rancangan Prototipe}

Hasil Rancangan prototipe dari penelitian ini adalah :

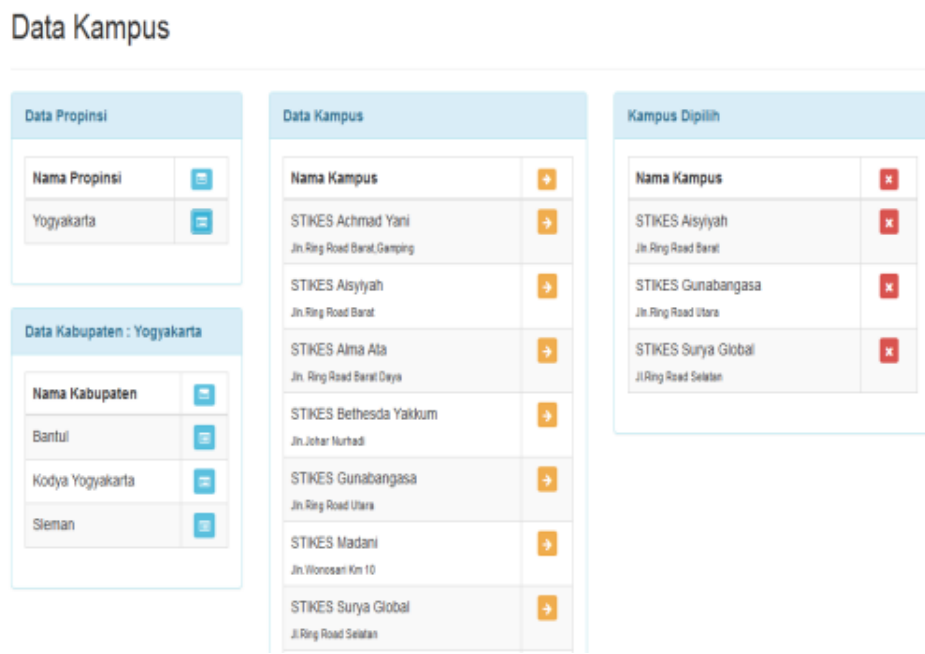

Gambar 7. List Data Kampus

Gambar 7. adalah menampilkan data kampus yang akan digunakan dalam memilih STIKES. 
Fuzzy AHP

OData Wilayah Data Kampus

WData Member $\mid$ D Data Kriteria

\section{Data Kriteria}

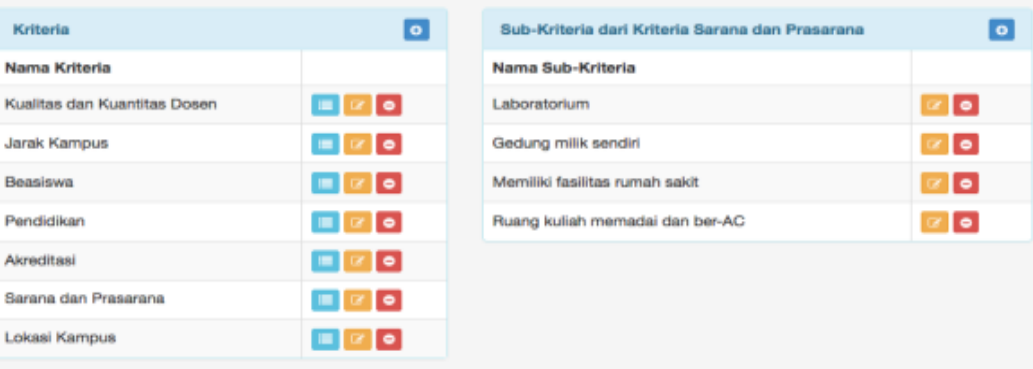

Gambar 8. Data Kriteria

Gambar 8. adalah menampilkan data Kriteria yang akan dipilih sebagai kriteria dalam memilih STIKES.

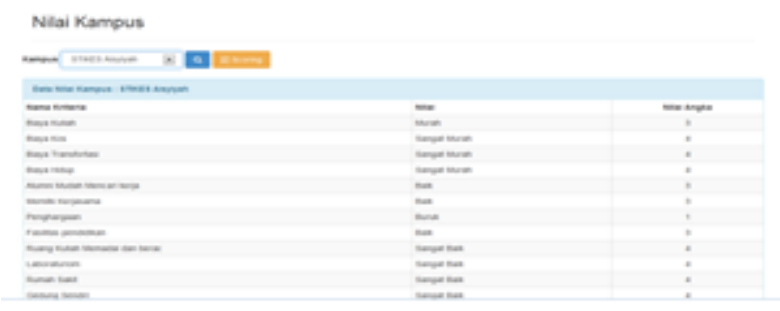

Gambar 9. Data Nilai Kampus

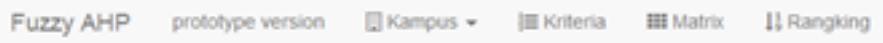

\section{Rangking Kampus}

\begin{tabular}{|c|c|c|c|}
\hline Nama Kampus & Eobot Clobal & Rangking & 뚱 \\
\hline STIKES Alsyyah & 1.95 & 1 & E \\
\hline STIKES Surya Global & 1.94 & 2 & E \\
\hline STikES Gunabangasa & 1.37 & 3 & 료 \\
\hline
\end{tabular}

\begin{tabular}{|c|c|c|}
\hline Nama Kriteria & Bobot Kriteria & Bobot Nalai Alternatit \\
\hline Baya Kulah & 0.82 & 0.43 \\
\hline Akrediasi & 0.11 & 0.43 \\
\hline Kualtas dan Kuanbtas & 0.21 & 0.37 \\
\hline Lokasi Kampus & 0.02 & 0.24 \\
\hline Jarak Kampus & 0.08 & 0.31 \\
\hline Baya Kos & .0 .1 & 0.27 \\
\hline Baya Transtortasi & 0.01 & 0.21 \\
\hline Alumni Mudah Mencari kerja & 0.07 & 0.36 \\
\hline Memikj Kerjasama & 0.09 & 0.27 \\
\hline Penghargaan & 0.83 & 0.37 \\
\hline Fasilatas pendidian & 0.01 & 0.20 \\
\hline Ruang Kulah Memadai dan berac & 0.68 & 0.43 \\
\hline Laboraturiom & 0.28 & 0.54 \\
\hline
\end{tabular}

Gambar 10. Hasil Data Ranking

Gambar 10. Hasil perangkingan kampus sesuai dengan hasil bobot kriteria maupun subkriteria dan nilai bobot alternatif sehingga menghasilkan nilai bobot global setiap masing- 
masing kampus, maka kampus yang mendapatkan nilai bobot global tertinggi akan mendapatkan ranking pertama.

Kelebihan dari penelitian ini adalah: 1) Menggabungkan 2 metode yaitu AHP dan FAHP, 2) Sampel kriteria yang digunakan berdasarkan hasil dari jawaban kuesioner yang diuji validitas disetiap variabelnya. 3) Perancangan prototipe berbasis web sehingga memudahkan dalam maintanace dan mengaksesnya.

Kekurangan dalam Penelitian ini adalah berupa prototipe belum berupa sebuah aplikasi yang sempurna sehingga membutuhkan pengembangan yang pada penelitian-penelitian selanjutnya.

\section{KESIMPULAN}

Kesimpulan yang dapat diambil dari Penelitian ini adalah 1) Perancangan prototype sistem pendukung keputusan dalam memilih STIKES menggunakan kriteria yang didapatkan dari hasil uji validitas disetiap variable kriterianya.2)Hasil dari penggabungan 2 metode yaitu AHP dan F-AHP ini dapat mengurangi penilaian secara subyektivitas dan mengecek konsistensi antar kriteria maupun subkriteria, sehingga dapat menghasilkan keputusan ranking sekolah tinggi ilmu kesehatan yang lebih objektif.3) Perancangan prototipe sistem pendukung keputusan dapat membantu memberikan pertimbangan atau rekomendasi kepada calon mahasiswa untuk mengambil keputusan dalam memilih STIKES.

\section{SARAN}

Pada Penelitian ini terdapat banyak kekurangan, sehingga dapat disempurnakan lagi pada penelitian-penelitian berikutnya. Maka agar prototipe menjadi aplikasi yang lebih sempurna pada penelitian-penelitian berikutnya, terdapat beberapa saran antara lain:1) Menentukan jarak kampus dari tempat tinggal bisa memanfaatkan google maps.2) Penambhan Fitur chatting, agar antar user bisa sharing pengalaman dalam memilih STIKES contoh kriteria atau faktor apa saja yang perlu jadi pertimbangan.3)Menambahkan fitur penentuan biaya secara otomatis yaitu dengan cara mengambil data biaya pendidikan dari web resmi setiap STIKES.4)Menambahkan fitur publish dan unpublish data kriteria oleh user, sehingga data kriteria tersebut dapat dilihat dan diaktifkan oleh user lain.

\section{DAFTAR PUSTAKA}

[1] Sukma, P., Serly, S.A., 2011, Sistem Pendukung Keputusan Untuk Menentukan Pilihan Minat Perguruan Tinggi Dikota Jambi Dengan Menggunakan Fuzzy Multi Criteria Decision Making, Seminar Nasional Aplikasi Teknologi Informasi 2011 (SNATI 2011), Yogyakarta, 17-18 Juni 2011.

[2] Kartikadarma, E., Zami, F. A., 2011, Desain Perangkat Lunak Pendukung Keputusan Pemilihan Perguruan Tinggi Bagi Siswa SMA Tingkat Akhir, Seminar Nasional Teknologi Informasi \& Komunikasi Terapan 2011 (SEMANTIK 2011).

[3] Jasril, Elin, H., Iis, A., 2011, Sistem Pendukung keputusan (SPK) Pemilihan Karyawan Terbaik Menggunakan Metode Fuzzy AHP (F-AHP), Seminar Nasional Aplikasi Teknologi Informasi 2011 (SNATI 2011), Yogyakarta, 17-18 Juni 2011.

[4] Kusrini, 2007, Konsep dan Aplikasi Sistem Pendukung Keputusan, Andi, Yogyakarta.

[5] Turban, E., 2005, Decision Support System and Intelligent Systems, Edisi Bahasa Indonesia jilid 1, Andi, Yogyakarta. 
[6] Mundir, 2013, Statistik Pendidikan, Pustaka Pelajar, Yogyakarta.

[7] Trihendradi. C, 2012, Step by Step SPSS 20 Analisis Data Statistik, Andi, Yogyakarta.

[8] Kabir, G., Hasin, M. A. A., 2011, Comparative Analysis of AHP and Fuzzy AHP Models for Multicriteria Inventory Classification, International Journal of Fuzzy Logic Sistems (IJFLS), Vol 1, No 1, hal 1-16.

[9] Chang, D. Y., 1996, Application of the Extent Analysis Method on fuzzy AHP, European Journal of Operational Research, hal 649-655. 